D. M. ZHELEZOV, G. S. MANASOVA, N. V. KUZMIN (Odessa, Ukraine)

\title{
REVISITING THE PECULIARITIES OF PREGNANCY AND CHILDBIRTH IN WOMEN WITH UTERINE SCARRING SYNDROME
}

Odessa National Medical University <gulsymmanasova@gmail.com>

In recent years, there has been an increase in the number of operations on the uterus in women of reproductive age with the formation of "uterine scarring syndrome" (USS), which can lead to complicated pregnancy and childbirth. To assess of anatomical and functional features of uterine scar, pregnancy and perinatal outcomes in USS women. A prospective analysis of clinical anamnestic data, pregnancy and childbirth in 398 USS women was conducted; ultrasound and Doppler assessment of morpho-functional status of the uterus using the Accuvix V20 Prestige (Samsung Medison, Republic of Korea) was made. Statistical analysis was performed using Statistica 13.0 (Dell Inc., USA) software. In $74.62 \%$ of 398 women, the scar on the uterus is due to a previous caesarean section (CS), in $24.11 \%$ due to conservative myomectomy (CME), in $1.25 \%$ - because of endoscopic interventions for incomplete uterine septum, in $25.87 \%$ of women it was the result of "small" gynecological surgery. In $97 \%$ of women with a scar on the uterus after the previous CS, there was no "passport of surgery": ultrasound revealed the localization of the scar in the lower uterine segment in $96.48 \%$ of 398 , corporate scar - in the remaining $3.51 \%$ of women; ultrasound signs of relative "anatomic" scar failure were noted in $10.80 \%$ of pregnant women. In $48.73 \%$ of women pregnancy was complicated by the threat of abortion or premature birth, in $30.40 \%$ anemia was diagnosed, in $24.87 \%$ of the women under observation placental dysfunction took place. $78.1 \%$ of women had delivery at term, $13.2 \%$ had premature birth, $97.3 \%$ had births CS, and $2.7 \%$ of women had labours through canalis obstetricus. In $1.3 \%$ of women labor was complicated by uterine hypotension, and uterine devascularization procedures was performed. The most common reasons for the formation of USS are cesarean section, conservative myomectomy and various "small" intrauterine operations. Pregnancy with this syndrome is most often complicated by the threat of its termination and childbirth before term, anemia, placental dysfunction and Intrauterine growth retardation. The choice of delivery tactics is conditioned by the totality of hystory, the status of the scar on the uterus, obstetric status and the wishes of the woman herself. It is advisable to look for methods to assess the morpho-functional status of the operated uterus and predict the perinatal consequences of pregnancy in these women at the stage of preconception preparation.

Key words: operated uterine syndrome; pregnancy; caesarean section; perinatal consequences.

Urgency. In recent years the number of surgical procedures on the uterus in reproductive age women has been increased worldwide. This leads to the subsequent formation of "uterine scarring syndrome" (USS), which can be a cause of complicated pregnancy and childbirth. The most common causes of USS are caesarean section (CS), conservative myomectomy (CME), and uterine plastic surgery account of abnormalities of uterine development or placenta accreta spectrum disorders $[1$, $3-5]$. A considerable number of these women have reproductive intentions $[1,2,9]$, and therefore the issue of prevention of complications during pregnancy and childbirth in this cohort $[1,2-3,5,6]$ is of particular relevance. The most threatening complications of pregnancy include localization of the placenta directly in the uterine scar; placental implantation; scar diastasis or rupture [6]. Diagnosis and monitoring of the ability of the uterine scar is carried out using modern imaging methods, which include ultrasound, hysteroscopy, MRT and CT, but the ultrasonographic method, with a verified safety during pregnancy, is considered the "gold standard" $[4,10]$. Ultrasound allows to determine the scar's thickness, the presence of recesses (niches) and other features that allow to predict its elasticity and the ability to with stand significant burdens during pregnancy and childbirth [11]. 
In USS presence, pregnancy is accompanied by a high frequency of various perinatal complications, repeated occurrences in the abdominal cavity are significantly increased, and maternal morbidity becomes 3-4 times higher than with childbirth through natural birth canal $[1,2]$. Despite the considerable and continuing interest of researchers, the optimization of pregnancy and childbirth in USS women, the diagnostic criteria of the anatomical and functional capacity of the operated uterus remains an important area of modern obstetrics.

Objective. To assess anatomical and functional features of uterine scar, pregnancy and perinatal outcomes in USS women.

Material and methods. On the basis of the perinatal center of the third level Communal health Protection Institution "Odessa Regional Clinical Hospital" during the 2016-2018, 13729 births were performed. 4729 or $34.4 \%$ of women had caesarean section births.

A prospective analysis of the course of pregnancy and childbirth was performed in 398 USS women, in 107 of them $(26.8 \%)$ the presence of two or more scars after CS was established.

The criteria for the patients selection was the history of surgical intervention on the uterus (cesarean section, conservative myomectomy or plasticity due to developmental abnormalities), time after the previous operation more than 2 years (taking into account the time of repair and restoration of morpho-functional status of myometrium), lack of extragenital pathology, pregnancy with one fetus.

Transabdominal (according to clinical protocols) ultrasound with the help of Accuvix V20 Prestige (Samsung Medison, Republic of South Korea) scanner was performed to all the patients at 11-13,19-22 weeks of gestation. Transvaginal ultrasound was performed to further visualize the scar after the previous CS. In dynamics, the transabdominal ultrasound of the scar area after CS was performed within 32 and 36-38 weeks.

Additionally, Doppler examination of the blood flow was performed in the uterine arteries, in the area of the scar on the uterus. All studies were performed after obtaining PICs.

Primary statistical analysis of the data was performed with descriptive statistics using Statistica 13.0 software (Dell Inc., USA); linear discriminant analysis was used to predict the ability of the uterine scar after a previous CS.

Results and discussion. The vast majority of the patients under examination were country women -230 or $57.7 \% ; 168(42.2 \%)$ of them were towns women. By social status, 115 or $28.8 \%$ of women were housewives, 107 (26.8\%) were manual workers, 95 (23.8\%) were employees, 81 women $(20.3 \%)$ were students. The average age of the patients was $(33.2 \pm 1.1)$ years.

In 297 women or $74.6 \%$, the uterine scar was due to a previous CS, in 96 or $24.1 \%$ it was conditioned by conservative myomectomy (presence of fibroids and, including, concomitant endometriosis), 5 women or $1.3 \%$ underwent endoscopic surgery on the account of incomplete uterine septum.

In all women, the intergenetic interval from the time of the previous surgery was more than 2 years.

In addition to these "large" gynecological surgeries, 103 women (25.9\% of 398) had a history of "small" surgery (scraping, hysteroscopy, etc.), which also alter uterus's morpho-functional status and are included in the concept of "operated uterus".

Among women operated on for uterine fibroids, 46 out of $96(47.9 \%)$ were expecting first births.

According to the anamnesis of the women with scars after CS, it was found that in the previous pregnancy, the main indications for surgical delivery were pelvic presentation of the fetus in $49(16.5 \%)$ of 297 , fetal distress - in $54(18.2 \%)$, obstructive births (anomalies of delivery, clinically narrow pelvis, etc.) in 111 
$(37.4 \%)$, progressive preeclampsia - in $12(4.1 \%)$, premature placental abruption in $18(6.1 \%)$ of 297 women. 141 patients or $47.5 \%$ had timely delivery and 156 or $52.5 \%$ of women had time urgent ones.

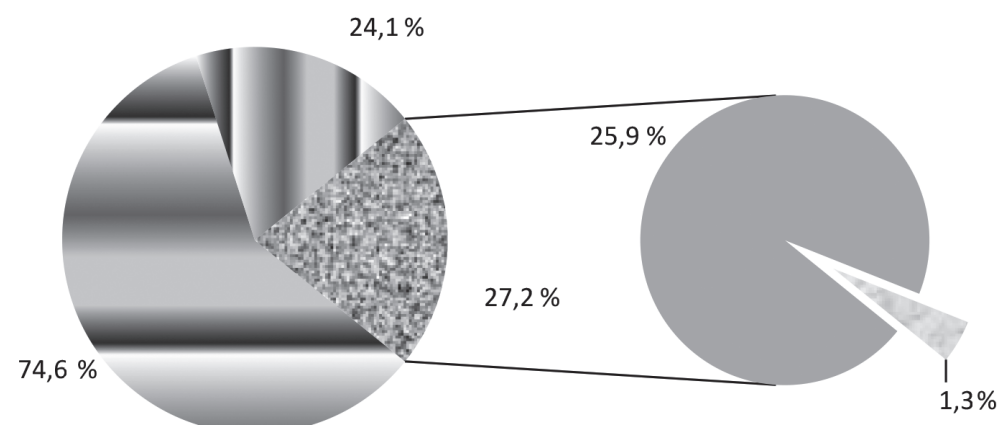

Fig. 1. Causes of the uterine scarring syndrome formation:

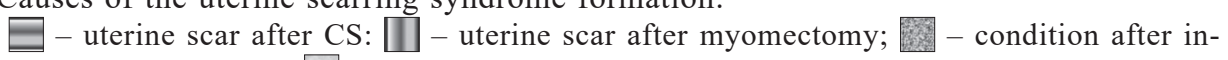
trauterine operations; $\square$ - scar after plastic surgery on the uterus

A careful history taking showed that the postoperative period was uneventful in $208(70.1 \%)$ of 297 women with scarring after CS. Other women (89 out of 297 or $29.9 \%$ ) indicated various problems after delivery: temperature rise was observed in 44 out of $89(49.4 \%)$, delayed discharge - in 36 out of $89(40.4 \%)$, pathological lactostasis - in 39 out of $89(39.7 \%)$, dysuric phenomena - in 18 patients out of $89(20.2 \%)$. Of 398 OUS women, 76 or $19.1 \%$ received antibacterial therapy.

It should be noted that almost $97 \%$ (386 out of 398) of uterus scar women after CS did not have a so-called "CS passport" with a clear description of the indications for surgery, type of uterus's incision, techniques for suturing the incision on the uterus, course postoperative period. It was necessary to orient by the term of pregnancy when the operation was performed and other indirect indications of the possible type of surgery and technique used. Ultrasound had a decisive role here and the localization of the scar in the lower segment was established in $384(96.5 \%)$ of 398 pregnant women, corporate scar was diagnosed in the rest 14 of 398 women or $3.5 \%$.

CME scar or metroplasty women did not report any complications after surgery. CME was performed by laparoscopic approach in 84 of 96 women or $91.3 \%$, while the remaining $12(12.5 \%)$ had a laparotomy. The average time after CME and metroplasty was $(2.7 \pm 0.2)$ years.

In patients with a scar on the uterus after CME, its localization corresponded to the primary localization of the removed myomatous node. The most frequently so-called "fundal" scars located in the uterine fundus (39 or $40.6 \%$ of 96 women) and corporate (37 or $38.5 \%)$ scars were onserved. In 10 (1.1\%) women the scar area was not identify. 10 women $(1.1 \%$ out of 96$)$ has history of multiple nodes removed, but the scar area was not clearly established. In this cohort of patients, the "passport" of the previous operation was in 72 of $96(75 \%)$, but in 21 of them $(29.2 \%)$ information about the localization and suturing of the "bed" of the remote myomatous node was absent. Another drawback of these records was the lack of information about penetration into the uterine cavity during myomectomy.

Extragenital status in 269 of $398(67.6 \%)$ pregnant women with USS was characterized by a number of diseases: $45(11.3 \%)$ had chronic pyelonephritis, 25 $(6.3 \%)$ - disorders of fat metabolism, $31(7.78) \%)$ - myopia of varying degrees, in $21(5.3 \%)$ there were gastrointestinal diseases, $30(7.5 \%)$ had neurocirculatory dystonia, $13(3.3 \%)$ - chronic arterial hypertension, 27 ( $6.8 \%)$ - chronic varicose veins. In general, the incidence of extragenital diseases was consistent with the population indexes. 
In the analysis of pregnancy in USS women the following features were revealed (Table). No statistically significant difference in pregnancy in patients with 1 or 2 scars on the uterus after CS was found.

Pregnancy complications in women with operated uterine syndrome

\begin{tabular}{|c|c|c|c|c|c|c|}
\hline \multirow{2}{*}{ Complications } & \multicolumn{2}{|l|}{1 trimester } & \multicolumn{2}{|l|}{2 trimester } & \multicolumn{2}{|l|}{3 trimester } \\
\hline & Absolute number & $\%$ & Absolute number & $\%$ & Absolute number & $\%$ \\
\hline Early gestosis & 89 & 22.4 & & & & \\
\hline Spotting & 91 & 22.8 & 34 & 8.5 & & \\
\hline $\begin{array}{l}\text { Threatening } \\
\text { miscarriage }\end{array}$ & & & 76 & 19.09 & 27 & 6.8 \\
\hline Low placenta & 47 & 11.8 & 21 & 5.3 & 12 & 3.01 \\
\hline $\begin{array}{l}\text { Placenta previa, } \\
\text { marginalis }\end{array}$ & & & 11 & 2.76 & 11 & 2.8 \\
\hline Anemia & 76 & 19.1 & 89 & 22.4 & 121 & 30.4 \\
\hline $\begin{array}{l}\text { Gestational } \\
\text { pyelonephritis }\end{array}$ & & & 27 & 6.8 & & \\
\hline Oligoamnios & & & 15 & 3.8 & 17 & 4.3 \\
\hline Hydramnion & & & 28 & 7.1 & 35 & 8.8 \\
\hline Preeclampsia & & & & & 32 & 8.04 \\
\hline Placental dysfunction & & & 81 & 20.4 & 99 & 24.9 \\
\hline $\begin{array}{l}\text { Intrauterine growth } \\
\text { retardation }\end{array}$ & & & & & 45 & 11.3 \\
\hline
\end{tabular}

In every second woman, pregnancy was complicated by the threat of interruption or the threat of preterm birth $(48.7 \%)$, in every third woman $(30.4 \%)$ anemia was diagnosed. On the basis of ultrasound and Doppler data of hemodynamic abnormalities of uterine-placental-fetal circulation, every fourth pregnant woman in the 3rd trimester had "placental dysfunction", realized in intrauterine growth retardation in $11.3 \%$ of the patients under observation.

According to ultrasound and Doppler examinations of the scar area after CS, ultrasound signs of relative "anatomical" scar failure were noted in 43 (10.8\%) of 398 women at 32 weeks gestation. Thus, the in homogeneity and irregularity of the scar along thickness of the myometrium was found in $38(9.5 \%)$ of 398 pregnant women, atypical location of the scar (above the area of the lower segment or its low location ) - in 24 (6.1\%) of 398 women. From these patients history it was established that the previous CS was produced urgently in the process of childbirth. In addition, thinning of the myometrium in the area of the scar (up to $2 \mathrm{~mm}$ ) was detected in 29 women (7.3\% of 398). A significant reduction in vascularization in the scar area was found in 29 of 398 pregnant women $(7.3 \%)$, which is characteristic of myometrium connective tissue degeneration.

The absence of complaints and any clinical manifestations of anatomic and functional inability of the scar on the uterus in this group of women allowed to prolong the pregnancy. An individual plan of pregnancy's management was developed, including supervision in the hospital, with dynamic cardiotocographic control of the state of the fetus, uterine tone and the general condition of the pregnant woman, providing psychological support, with the prevention of respiratory disorders syndrome in the fetus in the case of urgent delivery.

Despite the possibilities of modern diagnostic methods for assessing the condition of the scar on the uterus, there are no precise "mathematical" criteria for its anatomical and functional failure and the final choice about the method of delivery remains with the patient. In most cases, women in this group insist on termination of pregnancy by caesarean section. 
Pregnancy ended in 38-40 weeks in 343 (86.2\% of 398) women, 55 (13.2\%) women had premature labours at the term $33-36$ weeks. In all cases of preterm birth, caesarean section was produced.

Taking into account the wishes of women and their rejection of childbirth per vias naturalis, 311 USS pregnant women (78.1\% of 398) were delivered surgically abdominally in the planned order in the period of 39-40 weeks (Fig. 2).

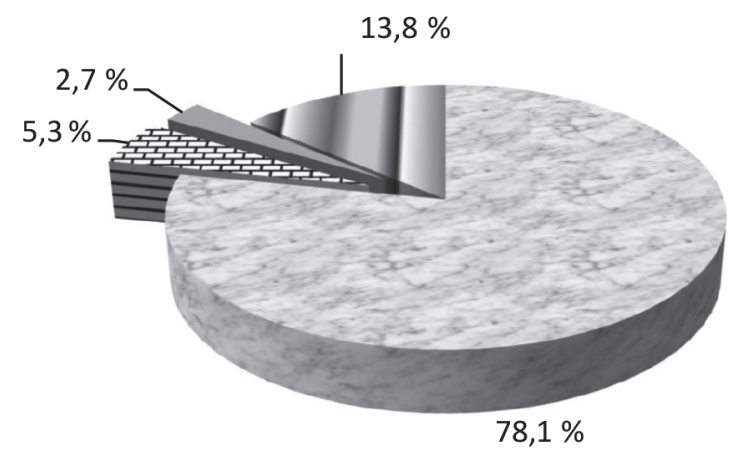

Fig. 2. Tactics features of pregnant women with the syndrome of the operated uterus delivery: 㯺 - scheduled CS on time; $\square$ - urgent CS on time; $\mathbb{\|}$ - childbirth per vias naturalis on time; $\square$ - premature birth CS

Urgently 21 women $(5.3 \%$ of 398$)$ were operated on in connection with fetal distress, obstructive births in the 1 st period of labor (14 or $66.7 \%$ of 21$)$, incorrect fetal position after bursting of waters (7-33,3\% of 21$)$.

It should be noted that 10 women in this group had an attempt of per vias naturalis births, but in the process obstructive of childbirth was developed (4 cases), fetal distress in 4 cases, in 2 cases women changed their decision and insisted on completion childbirth by caesarean section. Through natural birth routes $11(2.7 \%$ of 398) USS women delivered. 3 of them after CME (27.3\% of 11), 8 (72.7\%) after CS. In all cases of childbirth through the natural maternity ways regional methods of anesthesia of childbirth were applied.

The average blood loss during caesarean section was $(650 \pm 230) \mathrm{ml}$; in $5(1.3 \%$ of 387 caesarean sections) births were complicated by uterine hypotension, on this occasion an uterine devascularization procedures was performed. There were no cases of massive obstetric haemorage.

A total 398 children were born. The average weight of full-term infants was $(3475,67 \pm 354,23) \mathrm{g}$, the average height $-(52,70 \pm 3,81) \mathrm{cm}$. The average weight in preterm infants corresponded to $(1978,16 \pm 356,75) \mathrm{g}$, height $-(43,65 \pm 4,51)$ $\mathrm{cm}$. Apgar Score in the group of newborns suffering from distress amounted to 5 6 points (21 infants out of 398 or $5.3 \%$ ), $16.3 \%$ (65 out of 398 newborns) were evaluated at 6-7 points, 72 infants (18.1\% of 398) scored 7-8 points, the other 240 $(60.3 \%$ of 398$)$ had a score of $8-9$.

The postpartum period in 359 (90.2 \% of 398) women was satisfactory; 19 women $(4.8 \%$ of 398$)$ had uterine subinvolution, postpartum endometritis with fever up to $(38.80 \pm 2.40)^{\circ}$ was diagnosed in 8 cases $(2.1 \%), 12$ women $(3.1 \%$ of 398$)$ had lactostasis with temperature rise.

Thus, the analysis of the course of pregnancy and childbirth in women with uterine scarring syndrome allows to draw a number of conclusions.

Conclusions. The most common reasons for the formation of uterine scarring syndrome are cesarean section (74.62 \%), conservative myomectomy $(24.11 \%)$, various "small" intrauterine operations (scraping, hysteroscopy, etc.) $(25.87 \%)$. The complicated course of pregnancy in the presence of uterine scarring syndrome is caused by the high frequency of threatened miscarriage and premature delivery $(29,64 \%)$, 
anemia $(52,76 \%)$, placental dysfunction $(24,87 \%)$, intrauterine growth retardation $(11.3 \%)$. The choice of delivery tactics in the presence of uterine scarring syndrome is conditioned by the totality of the history data, examination and evaluation of the condition of the scar on the uterus with the use of visualization techniques and wishes of the woman herself. It seems appropriate to look for methods of assessing the morpho-functional status of the operated uterus and predicting the perinatal consequences of pregnancy in these women at the stage of pre-gravidar preparation.

Conflict of interest. There is no conflict of interest regarding the research, authorship and/or publication of this article.

\section{$\mathrm{R}$ e f e r e n c e s}

1. Гасанов Я. М. Ведение беременности и клиническая характеристика женщин с рубцом на матке после миомэктомии // Актуальні пробл. сучасної медицини: Вісн. Укр. мед. стомат. академії. 2015. - T. 15, № 3-2. - C. 101-103.

2. Чернова М. О., Самойлова Ю. В. Беременность и роды у женщин с рубцом на матке после кесарева сечения // Журн. акушерства и женских болезней. 2017. - T. LXVI (спецвыпуск). - C. 164-165.

3. Birch Petersen K., Hoffmann E., Rifbjerg Larsen C., Svarre Nielsen H. Cesarean scar pregnancy: a systematic review of treatment studies // Fertil. Steril. - 2016. - Vol. 105, N 4. P. 958-967.

4. Cali G., Timor-Tritsch I. E., Palacios-Jaraquemada J. et al. Outcome of Cesarean scar pregnancy managed expectantly: systematic review and meta-analysis // Ultrasound Obstet. Gynecol. - 2018. - Vol. 51, N 2. - P. 169-175.

5. Gonzalez N., Tulandi T. Cesarean Scar Pregnancy: A Systematic Review // J. Minim Invasive Gynecol. - 2017. - Vol. 24, N 5. - P. 731-738.

6. Jayaram P., Okunoye G., AlIbrahim A. A. et al. Expectant management of caesarean scar ectopic pregnancy: a systematic review // J. Perinat. Med. - 2018. - Vol. 46, N 4. - P. 365-372.

7. Kumar I., Verma A., Matah M., Satpathy G. Utility of multiparametric MRI in Caesarean section scar characterization and preoperative prediction of scar dehiscence: a prospective study // Acta Radiol. - 2017. - Vol. 58, N 7. - P. 890-896.

8. Monteagudo A., Romero J. A., Timor-Tritsch I. E. Pregnancy in an Abnormal Location // Clin. Obstet. Gynecol. - 2017. - Vol. 60, N 3. - P. 586-595.

9. Timor-Tritsch IE, Khatib N, Monteagudo A, Ramos J, Berg R, Kovács S. Cesarean scar pregnancies: experience of 60 cases // J. Ultrasound. Med. - 2015. - Vol. 34, N 4. - P. 601-610.

10. Timor-Tritsch I. E., Monteagudo A., Cali G. et al. Easy sonographic differential diagnosis between intrauterine pregnancy and cesarean delivery scar pregnancy in the early first trimester // Am. J. Obstet. Gynecol. - 2016. - Vol. 215, N 2. - P. 225-227.

11. Xiong X., Yan P., Gao C. et al. The Value of Contrast-Enhanced Ultrasound in the Diagnosis of Cesarean Scar Pregnancy // Biomed. Res. Int. - 2016. - Vol. 2016. - ID 4762785. - doi. org/10.1155/2016/4762785

\section{ДО ПИТАННЯ ПРО ОСОБЛИВОСТІ ПЕРЕБІГУ ВАГІТНОСТІ ТА ПОЛОГІВ У ЖІНОК З СИНДРОМОМ ОПЕРОВАНОЇ МАТКИ}

\section{Д. М. Железов, Г. С. Манасова, Н. В. Кузьмін (Одеса)}

Останніми роками спостерігається збільшення кількості операцій на матці у жінок репродуктивного віку з формуванням «синдрому оперованої матки» (COM), що може призвести до ускладненого перебігу вагітності та пологів. Мета дослідження - оцінка анатомо-функціональних особливостей рубця на матці, перебігу вагітності та перинатальних наслідків у жінок із СОМ. Матеріали і методи. Проведено проспективний аналіз клініко-анамнестичних даних, перебігу вагітності та пологів у 398 жінок із СОМ; здійснено в динамиці ультразвукову та доплерометричну оцінку морфо-функціонального стану матки за допомогою апарату Accuvix V20 Prestige (Samsung Medison, Південна Корея). Статистичний аналіз проведено за програмою 
Statistica 13.0 (DellInc., США). Результати та їх обговорення. Серед 398 жінок у 74,62 \% рубець на матці обумовлений попереднім кесаревим розтином (КР), у 24,11 \% - консервативною міомектомією (KME), 1,25 \% - ендоскопічним втручанням 3 приводу неповної перегородки матки, у 25,87 \% - «малими» гінекологічними операціями. У 97 \% жінок з рубцем на матці після попереднього КР не було «паспорту операції»: за допомогою УЗД встановлено локалізацію рубця в нижньому сегменті матки у 96,48 \%, корпоральний рубець - у решти 3,51 \% жінок; ехографічні ознаки відносної «анатомічної» неспроможності рубця відмічено у 10,8 \% вагітних. У 48,73 \% жінок вагітність ускладнилася загрозою переривання або передчасних пологів, у 30,4 \% - анемію, у 24,87 \% - дисфункцією плаценти. Розродження в термін відмічено у $78,1 \%$, дострокове - у 13,2 \%; шляхом КР - у 97,3 \%, у решти 2,7 \% - через природні пологові шляхи. У 1,3 \% пологи ускладнились гіпотонією матки, було проведено поетапну деваскуляризацію матки. Висновки. Найчастішими причинами формування синдрому оперованої матки є кесарів розтин, консервативна міомектомія і різні «малі» внутрішньоматкові операції. Вагітність при цьому синдромі найчастіше ускладнюється загрозою переривання вагітності і пологів до терміну, анемією, дисфункцією плаценти і затримкою внутрішньоутробного розвитку плода плода. Вибір тактики розродження обумовлений сукупністю даних анамнезу, стану рубця на матці, акушерського статусу і побажань самої жінки. Доцільний пошук методів оцінки морфофункціонального стану оперованої матки і прогнозування перинатальних наслідків вагітності у цих жінок на етапі прегравідарної підготовки.

Ключові слова: синдром оперованої матки; вагітність; кесарів розтин; перинатальні наслідки.

\section{К ВОПРОСУ ОБ ОСОБЕННОСТЯХ ТЕЧЕНИЯ БЕРЕМЕННОСТИ И РОДОВ У ЖЕНЩИН С СИНДРОМОМ ОПЕРИРОВАННОЙ МАТКИ}

\section{Д. М. Железов, Г. С. Манасова, Н. В. Кузьмин (Одесса)}

В последние годы наблюдается увеличение количества операций на матке у женщин репродуктивного возраста с формированием «синдрома оперированной матки» (COM), который может привести к осложнённому течению беременности и родов. Цель исследования - оценка анатомо-функциональных особенностей рубца на матке, течения беременности и перинатальных исходов у женщин с СОМ. Материалы и методы. Проведён проспективный анализ клинико-анамнестических данных, течения беременности и родов у 398 женщин с COM; в динамике проведена ультразвуковая и допплерометрическая оценка морфофункционального состояния матки с помощью аппарата Accuvix V20 Prestige (Samsung Medison, Южная Корея). Статистический анализ проведён с помощью программы Statistica 13.0 (DellInc., США). Результаты и их обсуждение. Из 398 женщин у 74,62 \% рубец на матке обусловлен предыдущим кесаревым сечением (КС), у 24,11 \% - консервативной миомэктомией (KME), у 1,25 \% - эндоскопическими вмешательствами по поводу неполной перегородки матки, у 25,87 \% - «малыми» гинекологическими операциям. У 97 \% женщин с рубцом на матке после предыдущего КС не было «паспорта операции»: с помощью УЗИ визуализирована локализация рубца в нижнем сегменте матки у 96,48 \% из 398, корпоральный рубец - у остальных 3,51 \% женщин. Эхографические признаки относительной «анатомической» несостоятельности рубца выявлены у 10,8 \% беременных. У 48,73 \% женщин беременность осложнилась угрозой прерывания или преждевременных родов, у 30,4 \% анемией, у 24,87 \% - дисфункцией плаценты. Родоразрешение в срок отмечено у 78,1 \%, до срока - у 13,2 \%; путём КР - у 97,3 \%, остальные 2,7 \% - через естественные родовые пути. У 1,3\% роды осложнились гипотонией матки, была проведена поэтапная деваскуляризация матки. Выводы. Наиболее частыми причинами формирования синдрома оперированной матки являются операция кесарева сечения, консервативная миомэктомия и различные «малые» внутриматочные операции. Беременность при этом синдроме часто осложняется угрозой прерывания беременности и родов до срока, анемией, дисфункцией плаценты и задержкой внутриутробного развития плода. Выбор тактики родоразрешения обусловлен совокупностью данных анамнеза, состояния рубца на матке, акушерского статуса и пожеланий самой женщины. Целесообразен поиск новых методов оценки морфофункционального состояния оперированной матки и прогнозирования перинатальных исходов беременности у этих женщин на этапе догравидарной подготовки.

Ключевые слова: синдром оперированной матки; беременность; кесарево сечение; перинатальные исходы. 